University of Pennsylvania Carey Law School

Penn Law: Legal Scholarship Repository

Faculty Scholarship at Penn Law

$1-2007$

\title{
The Effect of Judicial Expedience on Attorney Fees in Class
}

\section{Actions}

Eric Helland

Jonathan Klick

University of Pennsylvania Carey Law School

Follow this and additional works at: https://scholarship.law.upenn.edu/faculty_scholarship

Part of the Courts Commons, Dispute Resolution and Arbitration Commons, Economics Commons, Judges Commons, Law and Economics Commons, Legal Profession Commons, Legal Studies Commons, and the Torts Commons

\section{Repository Citation}

Helland, Eric and Klick, Jonathan, "The Effect of Judicial Expedience on Attorney Fees in Class Actions" (2007). Faculty Scholarship at Penn Law. 1122.

https://scholarship.law.upenn.edu/faculty_scholarship/1122

This Article is brought to you for free and open access by Penn Law: Legal Scholarship Repository. It has been accepted for inclusion in Faculty Scholarship at Penn Law by an authorized administrator of Penn Law: Legal Scholarship Repository. For more information, please contact PennlawIR@law.upenn.edu. 


\title{
The Effect of Judicial Expedience on Attomey Fees in Class Actions
}

\author{
Eric Helland and Jonathan Klick
}

\begin{abstract}
Judges facing exogenous constraints on their pecuniary income have an incentive to reduce their workload to increase their private welfare. In the face of an increase in caseload, this incentive will induce judges to attempt to terminate some cases more rapidly. In class action cases, failing to grant an attorney fee request will delay termination. This conflict is likely to lead judges to authorize higher fees as court congestion increases. Using two data sets of class action settlements, we show that attorney fees are significantly and positively related to the congestion level of the court hearing the case.
\end{abstract}

\section{INTRODUCTION}

Richard Posner (1993) was the first scholar to develop a rational-actor model of judicial behavior. Recognizing that individual Article III judges have effectively no control over their salaries, Posner argues that judges are likely to work significantly less than comparable individuals in private practice. That is, because the returns to diligence are relatively low for judges, judges are likely to choose a relatively high level of leisure in their utility maximization problem, all other things equal. ${ }^{1}$

In the class action context, settlements are likely to be attractive to

ERIC HElland is Professor of Economics at Claremont McKenna College. JONATHAN KLICK is the Jeffrey A. Stoops Professor of Law at Florida State University. The authors thank Ted Eisenberg and Geoff Miller for comments and access to their class action data. We also thank Ted Frank, Michael Greve, Dick Posner, and Alex Tabarrok for comments on earlier drafts.

1. Posner also includes a number of other arguments in the judge's utility function in addition to income (assumed to be given exogenously) and leisure. These include prestige, popularity, reputation, and avoiding reversal.

[Journal of Legal Studies, vol. 36 (January 2007)]

(c) 2007 by The University of Chicago. All rights reserved. 0047-2530/2007/3601-0007\$01.50 
a judge since a settlement will reduce the judge's workload, and it is unlikely that the approval of any given settlement will lower any of the other arguments in the judge's utility function. During the approval process, if a judge rejects the class action attorney fee request, termination will be delayed. The marginal cost of this kind of delay is likely to increase as the judge's court grows more congested. This generates a potential conflict between the judge's desire for expediency and his or her role as the monitor for the diffuse class members who are, practically speaking, unable to monitor their attorney's performance.

As Hensler et al. (2000, p. 119) explain, "Largely clientless consumer class action litigation holds within itself the seeds for questionable practices. . . . Procedural rules, such as the requirements for notice and judicial approval of settlements, provide only a weak bulwark against self-dealing and collusion. . . Judges who are constantly urged to clear their docket and are schooled to believe that the justice system is better served by settlement than adjudication may find it difficult to switch gears and turn a cold eye toward deals that-from a public policy perspective-may be better left undone."

In addition to the general problem identified by Hensler et al., which would seem to be endemic to the class action form, it might be the case that this problem is being exacerbated as courts grow increasingly congested. The rational-actor model of judicial behavior suggests a causal link between court congestion and attorney fees in class action cases and predicts a positive relationship between court congestion and attorney fees in class action settlements.

We provide an exposition of this hypothesis in Section 2 of this paper. We then discuss the data in Section 3 and describe the shortcomings and advantages of both data sources used in the analysis. Section 4 examines the effect of congestion on the attorney fees in the data sets and provides evidence that our results are not driven by endogeneity. Section 5 concludes.

\section{JUDICIAL BEHAVIOR}

Posner (1993) posits a very simple model of judicial behavior. The decision to become or remain a judge is dependent on the relative magnitude of the individual's expected utility as a judge and as a lawyer. By assumption, the individual earns a higher income as a lawyer but consumes less leisure and gets less psychic income from prestige and rep- 
utation. Posner assumes that only the leisure variable is a choice variable for most judges.

There are a number of different mechanisms through which judges are able to increase their leisure. Posner (1993) mentions allowing court queues to grow by expending less time and effort on the cases at hand. Taking this strategy to an extreme might not be optimal, however, since an expanding queue could induce legislators to increase the size of the judiciary, which leads to a decrease in judicial prestige. Alternatively, the collegiality of the bench may provide enough social sanction that allowing the queue to increase endlessly, effectively forcing more work on one's fellow judges, may not be optimal behavior from the judge's viewpoint. Although this concern will be attenuated a bit given the public good nature of judicial prestige, social pressures within the judiciary and society more broadly might constrain a judge's ability to allow queues to grow ever longer. ${ }^{2}$

An alternate strategy might involve seeking to terminate cases as quickly as possible, conditional on not making the types of mistakes that are likely to lead to reversal or public condemnation, which would decrease utility in Posner's model through the prestige and reputation arguments. Expediting termination in this way helps to limit the court queue, saving that resource for cases that are less easily terminated. This strategy allows for a lower expenditure of effort or, conversely, a greater consumption of leisure subject to the relevant constraints.

In this maximization problem, the shadow price of additional slack in the queue constraint grows as court congestion increases. That is, as the queue resource becomes increasingly scarce because of increased court congestion, the incentive to terminate cases quickly grows. ${ }^{3}$ This relationship suggests that we should find a positive relationship between court congestion measures and judicial expediency, all other things equal.

For the vast majority of cases before the judge, the optimal strategy is to encourage settlement (or plea bargaining in the case of criminal trials). Moreover, settlement is generally the optimal decision of litigants as well because it avoids the cost of going to trial. Further, as settlement represents an agreement between plaintiffs and defendants, the judge is

2. For example, a New York Times story singled out George B. Daniels, a federal district court judge in Manhattan, as leading the nation in motions pending for a period longer than 6 months (Weiser 2004)

3. A formal model of this effect and empirical support from Israeli courts are presented by Beenstock and Haitovsky (2004). They find that judges complete more cases as their caseloads grow and complete fewer cases when new judges are appointed to their court. 
generally under no obligation to review the terms of the settlement, if he or she is even aware of them, and under almost no threat of reversal on appeal. The case of class actions is slightly more complex. In the class action context, judges are supposed to monitor the interests of the members of the plaintiff class and ensure that they are being served by the proposed settlement. This monitoring is quite time intensive.

As Hensler et al. (2000, p. 445) describe,

Judges play a unique role in damage class actions: Without the judge's decision to grant certification, a class action lawsuit does not exist. Without the judge's approval, a lawsuit cannot be settled. Without a judge's decision to award fees, the class action attorneys cannot be paid. Moreover, judges have special responsibilities while the litigation is ongoing: They approve the form and content of notices to class members that a class action has been certified or settled; they determine when and where fairness hearings will be held, how long they will be, and who can participate; they decide whether non-class members can intervene in the litigation, and whether lawyers representing objectors will receive any compensation. Even after a case is resolved, judges may continue to play a role by overseeing the disbursement of settlement funds.

Thus the ideal mechanism for reducing class-action-related judicial workload, from the point of view of the judge, is expediting cases that are unlikely to be reversed on appeal. Monitoring of settlements by plaintiffs in class action cases is rarely likely to constrain a judge who is trying to clear his or her docket. Plaintiffs are joined together because it is not rational to bring individual suits in these cases. This also means, however, that it is not rational for plaintiffs individually to monitor the case closely. Moreover, attorneys have divergent interests from their clients with respect to settlement. Since the plaintiffs' attorneys can negotiate the fee independent of the award, and the fee is not negotiated with the clients but with the defendant in the case, there is an obvious agency problem.

The other group that monitors settlements is public interest groups. Public interest groups can challenge fees and awards, but such challenges are rare, which makes the judge principally responsible for monitoring fees and settlements.

Hensler et al. (2000) provide data that give some idea of the monitoring judges themselves face. They find that in six of the 10 cases they extensively studied, class members had no objections to the settlement. 
In the other four cases, where objections were filed, only one case resulted in an appeal of the judge's decision to approve the settlement.

In four of the 10 cases, there were interveners from or on behalf of the class. In two cases, other plaintiffs' attorneys who had filed similar class actions objected to the settlement. In only one case was the intervener a public interest attorney, and in the other, the state attorney general intervened. ${ }^{4}$ Only in the case of the public interest law-frem does. it appear that attorney fees were reduced. ${ }^{5}$ In fact, Hensler et al. (2000, p. 463) find that in three of the cases studied, "class council received more in fees and expenses than class members received altogether."

In essence, the presiding judge determines the size of attorney fees in class action settlements with few external constraints. Willging, Hooper, and Niemic (1996) provide further support for the proposition that judges face few constraints on their behavior with respect to granting attorney fees in class action cases. Of the 407 cases they studied, there were only 28 attempted interventions of any kind, not just with regard to fees, and the presiding judge allowed just 13 . Willging, Hooper, and

4. The cases in which no objections were raised were Roberts $v$. Bausch \& Lomb, No. CV-94-C-1144 (N.D. Ala. 1996), in which two other attorneys who filed similar claims settled with the defendant for fees only; Pinney $v$. Great Western Bank, No. CV 95-2110 (C.D. Cal. 1997), where there was one unsuccessful intervention by-a-private attorney; Graham v. Security Pacific Housing Services, No. 2:96-CV-132 (S.D. Miss. filed April 1, 1996); Selnick v. Sacramento Cable, No. 541907 (Cal. Super. Ct. 1996); and Inman v. Heilig-Meyers, No. CV 94-047 (Ala. Cir. Ct. Fayette County filed May 12, 1994). In In re Factor VIII or IX Blood Products (this litigation was known as Wadleigh v. RhonePoulenc Rorer Inc., No. 93 C 5969 [N.D. Ill. filed September 30 1993]; it was continued as In re Factor VIII or IX Concentrate Blood Products Litigation, MDL-986, No. 93 C 7452, until settlement when it became the Walker Settlement); Atkins v. Hacros Chemicals Inc., No. 89-23976 (La. Dist. Ct. Orleans Parish, 1996); In re Louisiana Pacific Siding Litigation, No. 95-879-JO (LEAD) (U.S. Dist. Ct. for the Dist. of Or., filed June 19, 1995); and Cox et al v. Shell et al., No. 18,844 (Tenn. Ch. Ct. Obion County 1995), either individual class members or victims' groups objected. Only in the Blood Products. case was an appeal filed, and it was dismissed after defendants agreed to allow two groups of class members to pursue individual lawsuits. In Martinez v. Allstate Insurance Co., No. 95-0809169-CV (Tex. Dist. Ct. Zavala County filed August 28, 1995)/Sendejo v. Farmers Insurance Co., No. 95-08-09165-CV (Tex. Dist. Ct. Zavala County filed August 30, 1995), the state attorney general intervened and obtained an additional $\$ 2$ million for "consumer protection."

5. In Graham v. Security Pacific Housing Services, the judge allowed Trial Lawyers for Public Justice to intervene. In response to that intervention, plaintiffs' attorney fees were reduced from $\$ 5.4$ million to $\$ 1.9$ million. In fact, in three of the cases the judge either did not inquire into or was unconcerned with (1) the likely redemption rate of coupons while basing the fee on the face value of the coupons, (2) the total amount the defendant was paying, or (3) a settlement fund that depended on plaintiffs coming forward to claim a $\$ 5$ payment. 
Niemic (1996) also find that while 104 cases of the 407 in their sample were appealed, 71 of those cases ended up being affirmed at the appellate level. The majority of these appeals concerned a certification ruling, with 83 of the 104 appeals occurring after a certification ruling. The Willging, Hooper, and Niemic (1996) analysis suggests that a judge is at far greater risk of being overturned on appeal if he or she does not certify a class than if he or she approves a large attorney fee.

Clearly then, one mechanism through which judges can safely expedite class action settlements is by giving attorney fee requests little scrutiny. Less judicial scrutiny will enable the defendant and the plaintiff's attorney to enter into a bargain that maximizes their surplus at the expense of the class members. Specifically, since the defendant cares only about minimizing total costs, the split between the plaintiff's attorney and the class members is inconsequential to it, and it also values a quick resolution. The plaintiff's attorney primarily cares about his or her fee, and, given the diffuse nature of the interests of the plaintiff class, there will be little pressure to rein in the fee request from the class itself. ${ }^{6}$ This setup implies that as judicial scrutiny declines, attorney fees, conditional on settlement amounts, will increase.

\section{DATA SOURCES}

Data problems and limitations have significantly hampered empirical research regarding litigation generally (see, for example, Helland, Klick, and Tabarrok 2005). For cases decided at trial, existing data sets are far from comprehensive, especially at the state level. Data on cases that settle before trial are even more incomplete, and since most cases are settled before trial, this data problem is particularly acute. Class action settlements, however, may prove to be an exception to this general dearth of data, since court approval of the settlement terms is required.

Regarding attorney fees in class action litigation, most existing research has been limited in its scope, focusing on only a few courts (for example, Willging, Hooper, and Niemic 1996) or substantive areas (for example, Lynk 1994). Eisenberg and Miller (2004) have taken a large

6. Hensler et al. (2000) find that attorney fees in the 10 cases they examined ranged from 5 percent of the settlement to 50 percent. However, since the actual amount collected by plaintiffs is often smaller than the settlement fund, attorney fees as a percentage of damages actually collected were closer to 50 percent on average, much higher than the one-third fee mark that is often cited or the one-quarter fee rate found in Eisenberg and Miller (2004). 
step forward in this regard by developing and analyzing a data set of class action settlements that spans both state and federal courts from 1993 to 2002 as well as multiple litigation fields.

The Eisenberg and Miller (2004) data were constructed from the Westlaw AllCases database, the Lexis Mega database, and the Commerce Clearing House Federal Securities and Trade Regulation Reporters. This technique generated 449 cases, and fee information was available in 417 cases (Eisenberg and Miller 2004). ${ }^{7}$ In general, we follow Eisenberg and Miller's (2004) specification for fees with the addition of the congestion measures described below. We do, however, drop all state cases from the data set since we have court congestion data only for federal courts. ${ }^{8}$. The dependent variable is the natural $\log$ of the fee amount in 2002 dollars.

We also include several controls used by Eisenberg and Miller (2004). ${ }^{9}$ Specifically, given their finding that settlement amount is a strong predictor of attorney fees, we control for the size of the settlement in constant 2002 dollars. We also include an indicator variable that equals one if the fees in the case were generated via the lodestar method. This method essentially constructs an hourly fee and is more commonly used in cases without easily quantifiable damages. We include the lodestar control because, in cases in which plaintiffs' attorneys are explicitly generating a record of billable hours, it may be easier to challenge fees and thus reduce the fee amount.

We also include a control, defendant pays, which equals one if the

7. In the data set, there is one extreme outlier with respect to our congestion measures, a case from the Northern District of Alabama in 1999. While there is nothing particularly interesting about this case itself (Garst v. Franklin Life Insurance Company, 1999 U.S. Dist. Lexis 22666), the Northern District of Alabama witnessed a surge in terminations per judgeship during that year due to the mass termination of more than 18,000 breast implant cases. During that year, Alabama's measure of terminations per judgeship was 3,441 , compared with the average of 442 in the data set. This number was high even for the Northern District of Alabama, which saw 843 terminations per judgeship in 1998 and 709 in 2000. For this reason, we have excluded this case from the results we present, although including it does not affect the sign or the statistical significance of any of our results.

8. Arguably, given the method Eisenberg and Miller used to construct the data set, dropping state cases may be preferable anyway, since the Westlaw and Lexis databases contain cases and settlements from only 20 percent of the states' state trial courts (while they contain cases and settlements from federal trial courts from every state), and there is no reason to believe that the included courts represent a random sample of state courts.

9. We do not present results using the Eisenberg and Miller (2004) risk variables because of the subjective nature of the risk determinations used in their data set. However, this does not affect our results. 
defendant pays a fee amount independent of the settlement fund. While the expectation is that this should not affect the fee amount, that is, the payout is the same for the defendant in either event, it may again facilitate fee challenges. As a practical data matter, in cases where the defendant pays the fee, the fee is not included in the award amount of the plaintiff class.

Eisenberg and Miller (2004) posit that the age of the case is a proxy for complexity. ${ }^{10}$ Another possibility is that the age of the case proxies for the time value of money if we assume that because most of the plaintiff's attorney's investment in the case is made early on he or she would need to be compensated for having to wait until settlement to recoup his or her investment. We include the variable following the Eisenberg and Miller (2004) specification. One concern is that the age of the case may be determined by congestion. For this reason, we have run the regressions with and without age (not reported), finding substantially the same results.

We also include controls for whether the case was an appellate opinion, under the assumption that concern about being reversed on appeal is reduced if the case has already been appealed and hence judges are allowed more leeway in setting fees. We include an indicator variable equal to one if an objection to the fees was filed. The expectation is that fees will be lower if an objection is filed because judges' ability to reduce congestion without the threat of being overturned on appeal is reduced if someone is actually monitoring the fees.

We include controls for whether the settlement fund did or did not include soft-dollar relief. Soft-dollar relief, such as coupons or injunctions, is more difficult to value, which makes it more difficult to determine the appropriate fee. Often, courts will value some soft-dollar relief when computing the gross settlement (as in the case of coupon settlements), whereas injunctive relief is generally not valued in the gross settlement. We denote the former case "beneficial relief" and the latter as "nonbeneficial relief," following Eisenberg and Miller (2004). Our expectation is that in cases with beneficial relief, fees will be lower on the assumption that courts will view coupons as a worse deal for plaintiffs than cash, whereas there is likely a positive relationship with the presence of nonbeneficial relief, assuming the injunction is seen as so-

10. We use the term "age" to maintain consistency with Eisenberg and Miller's data set, however, the term "duration" might be a bit more clear, as the variable measures the length of time between a case's filing and its settlement. 
cially valuable. We also include controls for whether the settlement class was identified, with the expectation that this will reduce fee amounts and percentages because certifying the class at least produces identifiable plaintiffs who might object to the fees in the case. Also, following Eisenberg and Miller (2004), we include dummies for case type and a linear time trend.

Finally, we control for whether or not a fee-shifting statute applied. Fee-shifting statutes often apply in cases in which large cash damages are unlikely, such as in civil rights cases. While Eisenberg and Miller's (2004) original analysis of the data parses the cases between fee-shifting and non-fee-shifting cases, given their belief that the underlying distribution of fees between the two case types is significantly different because the award amounts differ substantially between them, we chose to pool the cases so as not to shrink an already small data set. ${ }^{11}$

Thus the model estimated using the Eisenberg and Miller data is

$$
\text { Fee }_{i}=\alpha+\beta \times \text { Congestion }_{i}+\Theta \times \chi_{i}+\varepsilon_{i},
$$

where Fee is the natural log of the fee amount, Congestion is one of our measures of congestion, and $\chi$ are the independent controls suggested by the Eisenberg and Miller (2004) analysis as discussed above. In one other divergence from the original Eisenberg and Miller (2004) specification, we cluster our standard errors by year to account for the uneven distribution of cases in the data set through time. Clustering by years effectively weights the cases such that each year's worth of cases is given equal weight in determining the regression parameters. ${ }^{12}$

We make no independent attempt to verify the Eisenberg and Miller (2004) data. They are the most comprehensive data currently available, in both geographic scope and time period. Instead, we supplement the data with analysis from a more limited data source, the Federal Judicial Center's (FJC) data that were used in Willging, Hooper, and Niemic (1996). The FJC data cover all cases in the Eastern District of Pennsylvania, Southern District of Florida, Northern District of Illinois, and

11. We also analyzed models that allowed for interactions between fee-shifting status and the gross settlement amount (not reported). Those models generated substantially the same coefficients on our congestion measures as those presented here.

12. We are also concerned with the possibility that the Administrative Office of the U.S. Courts slightly changes its methodology in the collection of the congestion measure from year to year, so clustering by year would control for any within-year correlation of errors arising from measurement error in the congestion terms. Dropping this clustering or clustering by court instead of by year generates quantitatively similar signs and $p$-values for the coefficients on the congestion measures that are presented in our tables. 
Northern District of California. They cover all cases resolved between July 1, 1992, and June 30, 1994. There are 408 cases in total, of which 117 come from Pennsylvania, 72 from Florida, 117 from Illinois, and 102 from California.

The FJC data set is not a random sample but a field study. It covers the population of cases in that time period in those districts. The districts were not chosen at random and are not intended to be representative of all class actions in the federal courts.

The control variables in the FJC data are extensive but suffer from numerous missing values. For this reason, to maximize the useable number of observations, we do not include most of the covariates (we retain only gross settlement amount, the lodestar dummy, and a linear time trend), which leaves us with only 105 observations. However, we believe these data provide us with a useful robustness check since we can include district fixed effects to control for unobservables that may be correlated with fee awards and court congestion.

For our congestion measures, we use terminations per judgeship in the given court for the given year. This measure is collected by the Administrative Office of the U.S. Courts and is available for all district and circuit courts for the years $1992-2003 .{ }^{13}$ The terminations measure represents how many cases were disposed of in the court for the given year divided by the number of judgeships that exist in the court during that time.

Another measure of congestion we consider is the number of fitings made in a court per the number of judgeships in that court. This measure has the added benefit that the FJC actually provides a weighted measure of filings per judgeship that assigns a weight to each filing that accounts for the differing amounts of time various kinds of filings generally take to resolve. For example, average civil cases or criminal felony cases are assigned a weight of 1 , while a death penalty habeas corpus case is assigned a weight of 5.99. ${ }^{14}$ This congestion measure arguably accounts for the different case mix each judge faces depending on which court he or she serves. Summary statistics for both data sets and for the congestion measures we use are presented in Table 1.

13. Administrative Office of the U.S. Courts, Federal Court Management Statistics (http://www.uscourts.gov/fcmstat/index.html).

14. For a more detailed explanation of the weighting system, see Administrative Office of the U.S. Courts, Explanation of Selected Terms (http://www.uscourts.gov/library/fcmstat/ cmsexpl03.html). 


\section{RESULTS}

When examining the natural log of the attorney fees (in real 2002 dollars), as shown in Table 2, we find a positive relationship between congestion (in natural log form) and attorney fees in every specification, regardless of the congestion measure we use. Using terminations per judgeship as our congestion measure, we observe a coefficient that is statistically significant at the 2 percent level. The coefficient implies an elasticity of .15 , which means that when terminations per judgeship rise by 1 percent, we observe an increase in the fee amount of .15 percent on average.

Using weighted filings per judgeship as our congestion measure produces similar results. We observe a coefficient that is statistically significant at the 1 percent level. The implied elasticity of the regressions suggests that as weighted filings per judgeship increase by 1 percent, attorney fees increase by .08 percent.

It might be the case that our congestion measures suffer from endogeneity to the extent that attorneys seek out those courts that tend to award higher fees in order to file their class actions. If that was the case, court congestion and attorney fees would be jointly determined. To rule out that possibility, we present a specification in which we use criminal filings per judge as our measure of congestion. Criminal filings are likely to be orthogonal to attorney fees, which makes this measure a potentially good congestion proxy for our purposes since criminal cases will add to a court's docket. This specification also generates a positive and statistically significant coefficient, which implies an elasticity between fees and criminal filings of .06 .

For our covariates, like Eisenberg and Miller (2004), we find that the settlement amount has a statistically significant positive effect on fees. We find an elasticity of about .81 between fees and the settlement amount. This coefficient is statistically different than one, which implies that fees as a percentage of the settlement decline as the settlement amount goes up. This is also consistent with Eisenberg and Miller (2004).

The only other covariate with consistently statistically significant coefficients is the defendant-pays variable. We find a statistically significant negative effect, with fees being about 17-20 percent lower in cases in which the fee is determined separately from the settlement amount. We have no intuition as to why this might be the case. None of the other covariates (time trend, fee shifting, lodestar, age, appellate, objector, beneficial soft relief, nonbeneficial soft relief, and the existence of a 


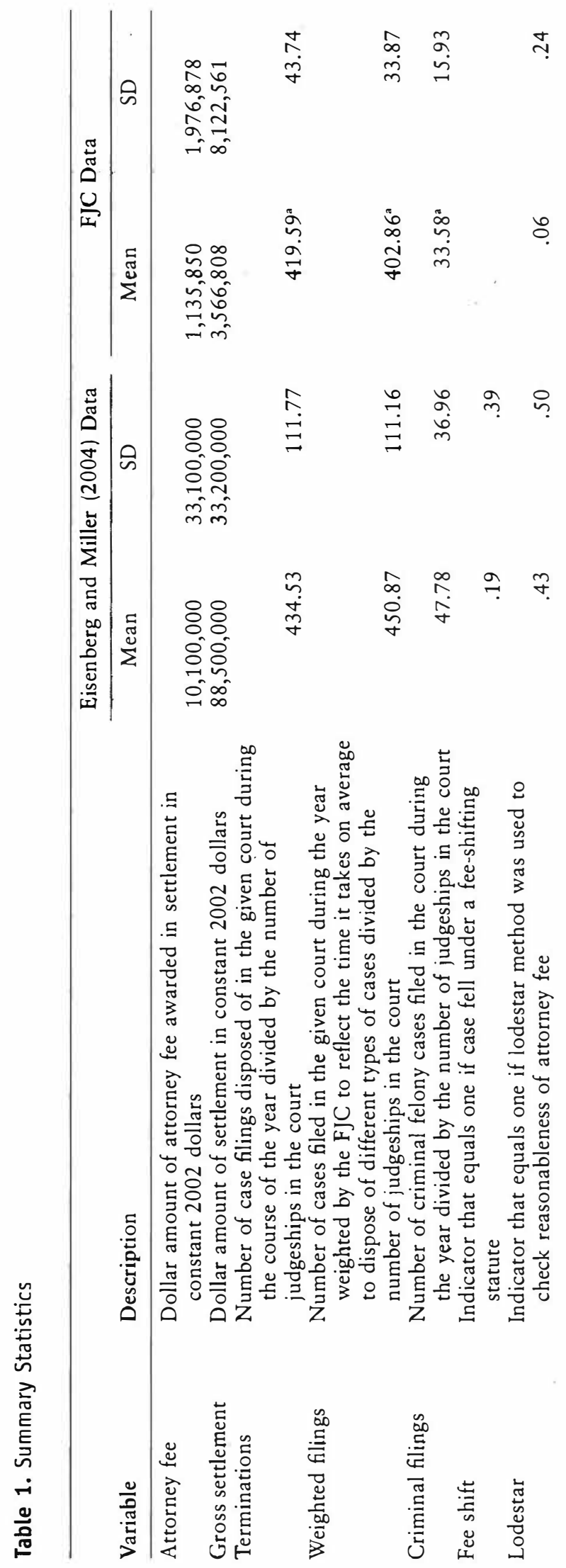




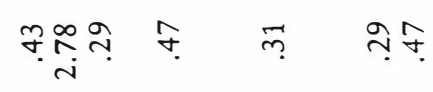

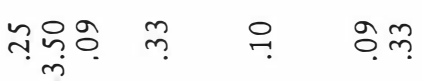

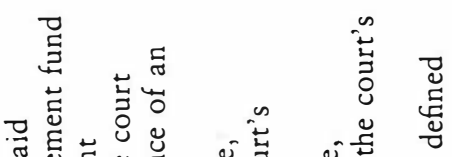

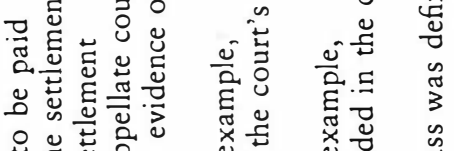

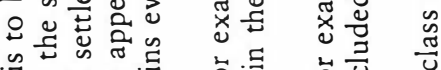

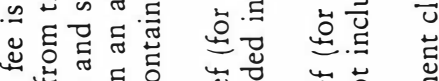

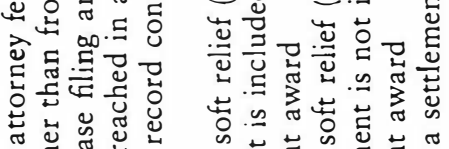

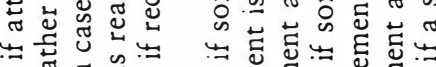

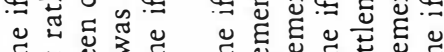

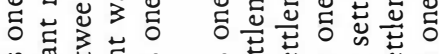

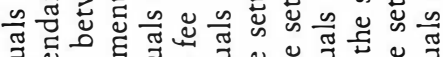

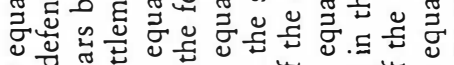

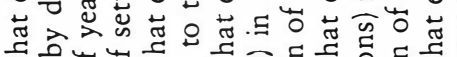

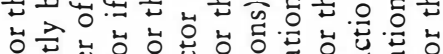

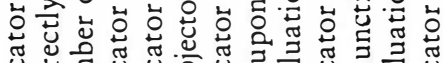

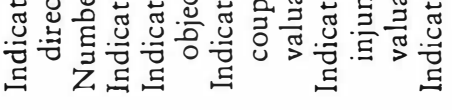

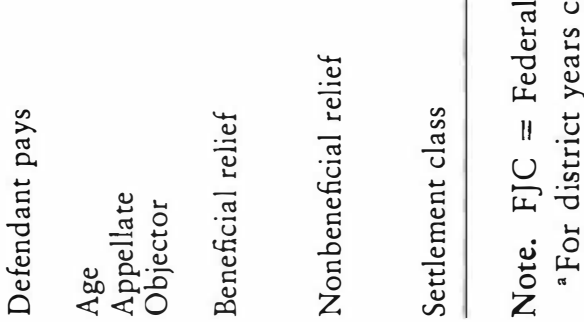


Table 2. Elasticity between Attorney Fees and Court Congestion

\begin{tabular}{|c|c|c|c|c|c|c|}
\hline \multirow[b]{2}{*}{$\ln ($ Terminations $)$} & \multicolumn{2}{|c|}{$(1)$} & \multicolumn{2}{|c|}{$(2)$} & \multicolumn{2}{|c|}{ (3) } \\
\hline & .153 & $(2.82)$ & & & . & \\
\hline $\ln$ (Weighted filings) & . & . & .084 & $(3.59)$ & . & \\
\hline $\ln$ (Criminal filings) & . & & $\ldots$ & . & .061 & (2.12) \\
\hline $\ln$ (Gross settlement) & .814 & $(48.18)$ & .825 & $(43.01)$ & .810 & (43.64) \\
\hline Year & -.003 & $(.05)$ & -.004 & $(1.13)$ & -.001 & $(.22)$ \\
\hline Fee shift & .081 & $(1.49)$ & .071 & $(2.01)$ & .098 & $(1.74)$ \\
\hline Lodestar & -.015 & $(.07)$ & .012 & $(.51)$ & -.017 & $(.82)$ \\
\hline Defendant pays & -.198 & (7.97) & -.171 & $(5.64)$ & -.194 & $(7.59)$ \\
\hline Age & -.003 & $(.05)$ & -.000 & $(.03)$ & -.004 & $(.71)$ \\
\hline Appellate & -.092 & $(1.01)$ & 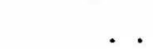 & & -.091 & $(.94)$ \\
\hline Objector & -.009 & $(.02)$ & -.040 & $(1.07)$ & -.011 & $(.28)$ \\
\hline Beneficial relief & -.025 & $(.92)$ & -.034 & $(1.85)$ & -.010 & $(.34)$ \\
\hline Nonbeneficial relief & .071 & $(1.11)$ & .046 & $(.76)$ & .066 & $(1.05)$ \\
\hline Settlement class & -.048 & $(1.42)$ & -.040 & $(1.12)$ & -.051 & $(1.56)$ \\
\hline$N$ & 297 & & 270 & & 297 & \\
\hline$R^{2}$ & .937 & & .946 & & .936 & \\
\hline
\end{tabular}

Note. The dependent variable is $\ln$ (attorney fee in 2002 dollars). The case data come from Eisenberg and Miller (2004). All regressions are estimated. with standard errors clustered by year and include case type dummies. The $t$-statistics are in parentheses. The appellate indicator is dropped from the specification using weighted filings per judgeship because the Federal Judicial Center does not have this metric for appellate-level courts.

settlement class) exhibit consistently statistically significant relationships with fee amounts.

In Table 3, we present regressions using the FJC data. Since we have multiple observations of cases from the same courts, we can include court fixed effects in this set of regressions to provide confidence that our congestion effect is not simply the result of some unobservable court effect. That is, it could be the case that courts awarding high fees also happen to have high levels of congestion (that is, reverse causation or simultaneity bias). Unfortunately, because of missing observations, we have fee award data for only 123 cases, and that number drops significantly if we add in any covariates. If we retain the gross-settlement variable, our usable observations drop to 105 , but given the predictive power of settlement size, the trade-off would appear- to be justified. We can also include a lodestar dummy and a linear time trend without losing any more observations. We present the results using the FJC data merely to serve as a robustness check for our primary findings about the relationship between court congestion and fees, keeping in mind that the ability to control for court fixed effects does provide some precision that we were unable to attain with the Eisenberg and Miller (2004) data. 


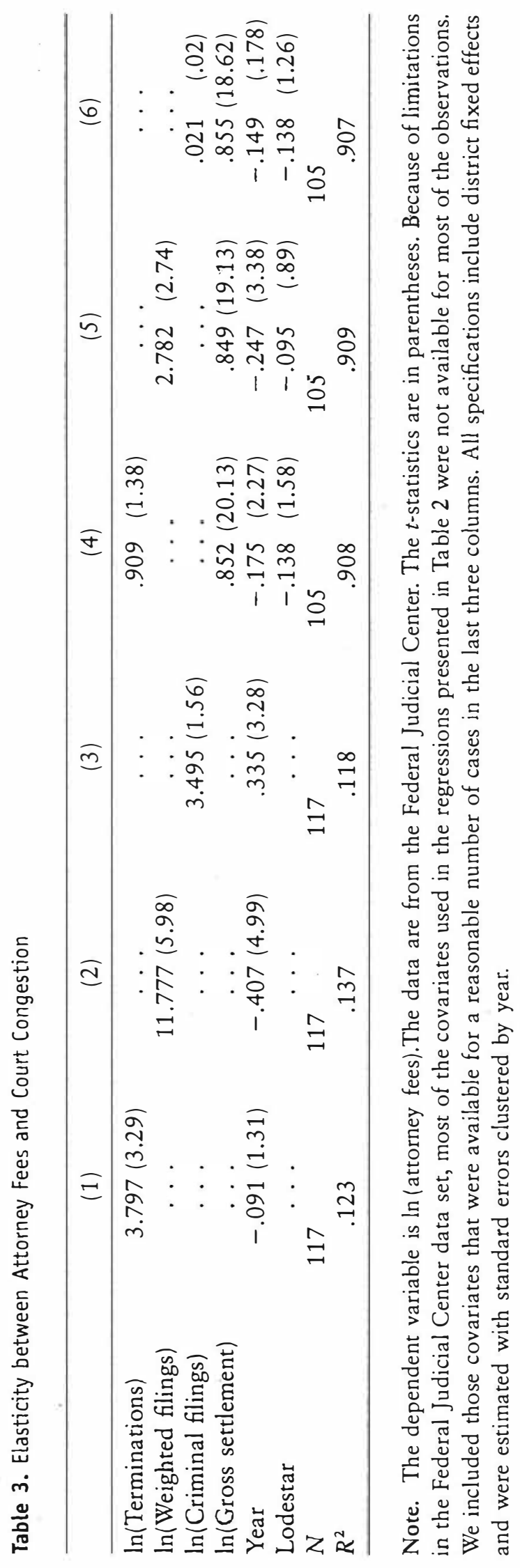


In Table 3, we present results using the FJC data to examine the effect of our congestion measures on attorney fees. In the specifications where we control only for a linear time trend and district fixed effects, two of our three congestion measures generate statistically significant positive elasticities. The coefficient on criminal filings per judge, while positive, is not statistically significant. Once we control for the gross settlement amount and a lodestar dummy, all three measures of congestion generate positive coefficients, but only the measure of weighted filings per judge is statistically significant. Because we have relatively little variation in within-district congestion, controlling for district effects limits the predictive power of our congestion measures.

\section{CONCLUSION}

Civil litigation has a large impact on economic welfare in the United States. According to the 2004 Economic Report of the President, "[T]ort liability leads to lower spending on research and development, higher health care costs, and job losses" (Council of Economic Advisors 2004, p. 203). However, much of this cost is justified by the deterrence and insurance functions performed by the tort system.

Some critics contend that we are in the midst of a torts crisis, with the costs of the system starting to outpace the benefits derived from it. Further, some commentators argue that attorneys themselves are at the root of this crisis (Olson 2003). One charge levied in this line of argument is that lawyers who bring class action suits against firms effectively subvert the democratic process by engaging in regulation through litigation without generating much gain for the individuals who are ostensibly their clients. That is, although class action suits generate substantiat judgments and settlements, it is claimed that an increasingly large portion of those proceeds are directed toward attorney fees, leaving a relatively meager amount to compensate those who have been harmed.

However, we are left with the question as to why attorneys are able to collect these high fees. One possibility is suggested by Posner's (1993) work on judicial behavior. Specifically, judges might have the incentive to expedite the settlement of class action cases by agreeing to attorney fee requests as standard operating procedure. In so doing, they decrease the amount of time and effort spent on the case, clearing it from their docket in a way that is unlikely to hurt their reputation. As court con- 
gestion increases, we should expect lawyers to seek and get increasingly high fees (see also White 2005).

We present results from two data sets on class action settlements that support Posner's hypothesis. Specifically, we find a positive and statistically significant correlation between court congestion and attorney fees. This result is robust and does not appear to be an artifact of endogeneity.

\section{REFERENCES}

Beenstock, Michael, and Yoel Haitovsky. 2004. Does the Appointment of Judges Increase the Output of the Judiciary? International Review of Law and Economics 24:351-69.

Council of Economic Advisors. 2004. Economic Report of the President. Washington, D.C.: U.S. Government Printing Office.

Eisenberg, Theodore, and Geoffrey Miller. 2004. Attorney Fees in Class Action Settlements: An Empirical Study. Journal of Empirical Legal Studies 1:27-78.

Helland, Eric, Jonathan Klick, and Alexander Tabarrok. 2005. Data Watch: Torturing the Data. Journal of Economic Perspectives 19:207-20.

Hensler, Deborah, Nicholas Pace, Bonita Dombey-Moore, Beth Giddens, Jennifer Gross, and Erik Moller. 2000. Class Action Dilemmas: Pursuing Public Goals for Private Gains. Santa Monica, Calif.: Rand Corporation.

Lynk, William. 1994. The Courts and the Plaintiffs' Bar: Awarding the Attorney's Fee in Class Action Litigation. Journal of Legal Studies 23:185-209.

Olson, Walter. 2003. The Rule of Lawyers: How the New Litigation Elite Threatens America's Rule of Law. New York: St. Martin's.

Posner, Richard. 1993. What Do Judges and Justices Maximize? (The Same Thing Everybody Else Does). Supreme Court Economic Review 3:1-41.

Weiser, Benjamin. 2004. Judge's Decisions Are Conspicuously Late. New York Times, December 6.

White, Michelle J. 2005. Asbestos Litigation: Procedural Innovations and ForumShopping. Journal of Legal Studies 35:365-98.

Willging, Thomas E., Laurel L. Hooper, and Robert J. Niemic. 1996. Empirical Study of Class Actions in Four Federal District Courts: Final Report to the Advisory Committee on Civil Rules. Federal Judicial Center, Washington, D.C. http://www.fjc.gov/public/pdf.nsf/lookup/rule23pdf/\$file/rule23.pdf. 